\title{
Addressing Cultural Diversity in Academic and Research Libraries
}

\section{Otis A. Chadley}

This article discusses the current state of cultural diversity in U.S. academic research libraries. It reports the results of a survey undertaken by the author in 1990 and mailed to the directors of 104 U.S. Association of Research Libraries member libraries. The survey asked about cultural diversity in research libraries in relation to recruitment of librarians, services to students, and collection development. Recent studies suggest research libraries must be prepared to examine their practices and make adjustments if they wish to provide quality service to all clientele. Results of the survey indicate that overall, research libraries are making increased efforts to create a more culturally diverse environment. More sustained effort is needed to attract underrepresented minorities to the research library work force. This article discusses the efforts being made and offers several suggestions to assist research libraries in their attempts to become truly multicultural institutions.

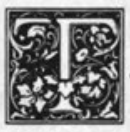

oday people of color comprise more than $20 \%$ of the U.S. population. According to the U.S. Bureau of the Census, four minority groups are particularly noteworthy because of their size. They include African Americans, Hispanics, Asian Americans and Pacific Islanders, and American Indians, including Alaskan natives (Aleut and Eskimo). Census projections for 1990 indicate that African Americans comprise $12 \%$ of the total national population and Hispanics represent $8 \%$. The most recent U.S. Census Bureau estimates indicate that Asian Americans and Pacific Islanders in 1988 comprised $3 \%$ of the total U.S. population, and that American Indians, including Alaskan natives, represented $.7 \%$. $^{1}$ Kathleen Falcigno and Polly Guynup report that by the end of the 1990s this same composite of minorities will comprise almost one-third of the American population. ${ }^{2}$
The dramatic changes already underway in American society are having a significant impact on colleges and universities. As the racial makeup of the student body changes, pressure grows for greater diversity in campus administrations and in the faculty and staff, including the library personnel of colleges and universities. Increasing pressure exists for diversity in the curriculum as students demand multicultural courses and materials that reflect their own experiences. In addition to these demands, students want materials that echo their own voices in their own languages. The pressure for change is real and immediate. As higher education changes to meet these challenges and pressures, so too must research libraries acknowledge, comprehend, and respond to these challenges and pressures in order to provide quality library services to all clientele and access to collections

Otis A. Chadley is Reference Librarian at the University Libraries, University at Albany, State University of New York, Albany, New York 12222. 
which reflect the lives and experiences of all Americans.

The U.S. Department of Education reports that the student body on academic campuses has become more heterogeneous, with minorities comprising $18 \%$ of the total student body in higher education in $1988 .{ }^{3}$ James E. Sulton, Jr., and other scholars suggest that one ramification of the growing diversity now under way on U.S. campuses is the rise of racial incidents and believe it imperative that higher education act quickly and responsively to demographic changes. ${ }^{4}$ Judith $\mathrm{H}$. Katz defines a "quality education" as "one that facilitates students' ability to interact effectively with diversity of ideas, of style, of culture, and of race." ${ }^{5}$ Academic research libraries, like their parent institutions, are beginning to recognize the need for action to address cultural diversity in higher education. The March 1990 Association of Research Libraries (ARL) newsletter declared: "Research libraries throughout North America must be prepared for the changes which the 1990s will bring if they are to play a more strategic role on campus."6

Perhaps of greatest significance to the future of academic research libraries is the state of minority enrollment in library and information science. In 1987, 490 minority students were enrolled in ALA-accredited master's programs. ${ }^{7}$ In 1988 , there was a $40 \%$ increase (195 individuals) in minority enrollment or a total of 685 minority students. ${ }^{8}$

By 1990, the growth rate had declined significantly; 819 members of underrepresented groups were enrolled in master's degree programs in library and information science, an increase of 134 persons, or a $20 \%$ growth rate. These data indicate that the growth rate in minority enrollment has slowed by $50 \%$ between the years 1988 and 1990 . The numbers remain small compared to the $91 \%(8,295)$ nonminority students enrolled in master's programs in library and information science in $1990 .^{9}$ In 1989, according to the most recent data available, 21 out of 29 fields of graduate study awarded more master's degrees to members of under- represented groups than did the field of library science where only $8 \%$ of those receiving master's degrees were underrepresented minorities. In each of ten disciplines, minority graduates exceeded $10 \%$. $^{10}$

Recruitment of members of underrepresented minority groups presents a significant challenge for academic research libraries and the library profession in general. U.S. Census figures for 1988 indicate that black librarians comprised $8 \%$ of the total library work force and Hispanic librarians represented only $2 \% .{ }^{11}$ In ARL libraries, for example, underrepresented minorities comprised only $10 \%$ (820) of all positions in 1990 . Of these minority librarians, over half (412) were Asian American, onethird were African American (272), and only $15 \%$ (125) were Hispanic. American Indians and Alaskan natives comprised only $2 \%$ (11) of the total number of minority librarians. ${ }^{12}$

\section{Recruitment of members of under- represented minority groups presents a significant challenge for academic research libraries.}

Library professional associations, library educators, and the directors of the nation's academic and research libraries have been growing increasingly concerned about the small number of minority students enrolled in library schools, the small number of minority librarians working in the profession, and the need for a more culturally diverse work force in academic and research libraries. In 1989, the Association of College and Research Libraries (ACRL) created the ACRL Task Force on Recruitment of Underrepresented Minorities to examine issues of minority recruitment and retention in academic libraries and advise the ACRL Board of Directors on necessary action. In its 1990 report, the ACRL Task Force expressed concern that the ACRL needs to reflect more accurately the ethnic and cultural diversity of American society and made suggestions about minority recruitment. ${ }^{13}$ In response to 
the Task Force report, the ACRL Board created, in November 1990, the Standing Committee on Racial and Ethnic Diversity to "initiate, advise, and mobilize support for appropriate action related to issues of racial and ethnic diversity in academic librarianship including the recruitment, advancement and retention of underrepresented groups to academic librarianship; and the promotion of quality academic library and information services for members of racial and ethnic groups." 14

The Association of Research Libraries (ARL) has also taken recent action to examine the issues of recruitment and retention of underrepresented minorities to the work force of the nation's largest research libraries. Following a general membership discussion of the issues, the ARL Board of Directors (in May 1990), established the Task Force on Minority Recruitment to "develop a series of recommendations on possible ARL initiatives to strengthen the recruitment and employment of minorities for professional positions in research libraries."15 The report of this group was reviewed at the ARL 1991 spring meeting. During the 1990 ALA Annual Conference, the ARL showcase booth theme was "Encouraging Cultural Diversity in Academic and Research Libraries." 16 This event was received by a substantial audience as more than 500 people visited the booth. ${ }^{17}$

Individual college and research libraries have also provided leadership on these issues. The University of Michigan Library has taken major steps toward creating a multicultural library environment. Minority library staff now comprise $20 \%$ of the library's work force. ${ }^{18}$ The library at UCLA has created a mentor program called REFORM/UCLA which "pairs successful Hispanic librarians with young Hispanics to encourage them to prepare for careers in librarianship." 19 The libraries of the University of California at Santa Cruz and the University of Michigan have created new positions focused on multiculturalism and diversity. ${ }^{20}$ These and other actions by college and research libraries and by li- brary professional associations are indicative of the serious efforts under way to respond to the challenges of new student populations and the pressures of rapidly changing demographics.

To learn more about what the nation's largest research libraries were experiencing in relation to cultural diversity, the author conducted a survey of ARL libraries in the fall of 1990 . As an employee of an ARL institution and a member of an underrepresented group in the library profession, the author was interested in learning about the current state of cultural diversity at other academic research libraries. Data for this project were collected through a survey instrument developed by the author and based on a review of the literature and more than 12 years of professional library experience. The survey consisted of 24 questions covering such topics as cultural diversity in collection development, recruitment of personnel, instruction programs, and user services. The questionnaire was sent to the directors of the 104 ARL libraries in the United States. All responses were anonymous. Of the 104 ARL institutions which received the survey, 49 responded and 35 of these were complete and usable for a $34 \%$ response rate. Both the timing of the survey and the way in which it was constructed may have affected the response rate. Directors received the questionnaire in November 1990, the most demanding time of the year. Also, the author should have developed the survey instrument for quick response rather than time-consuming answers. Individuals with relatively limited experience in constructing mail questionnaires usually receive not more than a $50 \%$ response rate in social science research. $^{21}$

\section{RECRUITMENT}

Of the $\mathbf{3 5}$ libraries that responded, 30 provided demographic information about the number of underrepresented minority librarians on their staff. These 30 libraries employ 1,703 librarians, of which 169 or $10 \%$ are from underrepresented groups (as compared to $10 \%$ for all ARL libraries). ${ }^{22}$ The range is from 
no minority librarians on a staff of 40 librarians to 36 minority librarians on a staff of 66 librarians. The results averaged to approximately six minority librarians employed at each institution. The most represented minority group is Asian American (50 percent). African Americans account for $29 \%$ of the group. Hispanic Americans account for 18\%, and the least represented group is American Indians at 3\%.

Materials collected.... can and must reflect the experiences of all Americans.

Fifty-seven percent of responding libraries consider their efforts at recruiting minority librarians as moderately successful or successful. Nevertheless, the numbers of underrepresented minorities on their staff are extremely small. The most represented minority group, Asian Americans, comprise an average of only three librarians for each library, while African Americans average only two librarians per institution and Hispanics average only one librarian per institution. The least represented group is American Indians with an average of less than one (.16) librarian per institution.

A 1990 survey of hiring practices in ARL libraries states that "an argument may be made for doing more to recruit protected classes ... however, it would seem that most ARL members are aware of the principles of equal employment opportunity and affirmative action, and are concerned enough to incorporate those principles into their hiring practices. ${ }^{23}$ However, research libraries may have created barriers to employment that discourage minority students from choosing to specialize in academic librarianship. Those barriers include low entry-level salaries, pay inequities among minority librarians and nonminority librarians, the requirement of previous library experience, and the barrier of both conscious and unconscious racism on the part of individuals and institutions. Em Claire Knowles cautions that "a serious commitment to library diversity requires an examination of low entry level salaries and limited salary ranges, which can discourage people of color from choosing a career in librarianship." ${ }^{24}$ While these barriers may present problems for anyone entering the profession, they may be particularly pernicious barriers to members of underrepresented minorities. Consequently, a career in librarianship that promises low pay and little social prestige is often less of an inducement for minorities than for most nonminorities considering library science as a career.

Given the realities of the distribution of income and opportunity in the U.S. population, minority graduates are more likely to incur considerable debt to finance their education and, therefore, low entry-level salaries represent a particularly insurmountable barrier to employment in librarianship. Moreover, for those minority members who have encountered unfair hiring practices and have experienced discrimination in employment, requiring previous library experience or specialized training may erect yet another barrier and prevent them from being considered in the applicant pool. Compared to white middle class America (still the primary recruiting source from which librarians are drawn), fewer minorities have a similar level of comfort, economic security, and education.

The 1990 ARL salary survey reports that minority librarians employed at ARL libraries in the United States in 1990 earned $4 \%(\$ 1,621)$ less, on average, than nonminority librarians, "despite the fact that minority professionals have $1 \%$ (approximately 2.5 months) more experience, on average, than their non-minority colleagues. The salary differential has increased by $1 \%$, or $\$ 459$, since last year's report." 25 Joseph A. Boisse and Connie V. Dowell point out that seldom do academic research libraries hire librarians without previous library experience, thereby reducing the number of entrylevel positions available and limiting opportunities for recent minority library graduates. ${ }^{26}$ The outcome of such hiring 
practice is that minorities not only have fewer library career opportunities to begin with, but they also are prevented from gaining crucial professional experience that is necessary for advancement. The ACRL Task Force on Recruitment of Underrepresented Minorities emphasizes how individual and institutional racism also can discourage people of color from seeking employment at academic research libraries. ${ }^{27}$

\section{INTERNSHIPS}

Internships, focused on recruiting underrepresented minority students into librarianship, as well as on recruiting recent minority library school graduates for beginning-level positions, are seen by some librarians as effective recruiting tools. Of the $57 \%$ of ARL survey respondents who consider their recruitment of minority librarians as moderately successful or successful, only three libraries had some form of internship program for recruiting minority graduate students or minority librarians. Nearly $20 \%$ of all responding ARL libraries reported that they had a minority internship program; however, several indicated that these were newly instituted programs and had not had time to be successful as yet. Less than $1 \%(.07)$ of the ARL institutions that consider their recruitment of minority librarians as unsuccessful report having some form of library internship. These internships, however, were open to all applicants and were not specifically targeted to minority applicants.

\section{MULTICULTURAL SERVICES LIBRARIANS AND INSTRUCTION PROGRAMS}

The value of developing a diversity or multicultural services position to attract underrepresented groups to the library should not be underestimated. Allan G. Dyson reports that subsequent to the University of California at Santa Cruz' developing a position of multicultural services librarian, more students from underrepresented groups are now using the library. ${ }^{28}$ Services provided by the multicultural services or diversity librarian may include bibliographic instruc- tion, one-on-one contact, outreach around the campus, and visits to high schools and public libraries. Clientele may include minority groupstudents, reentry students, and international students. Only five of 34 responding ARL libraries (15\%) indicated that they had a similar position in their library. Interestingly, three of these five libraries thought that they had been successful in attracting minority librarians to their libraries, and these three also had active internship programs.

\section{Research libraries may have created barriers to employment that dis- courage minority students from choosing to specialize in academic librarianship.}

The duties of the multicultural services librarian, as reported by the respondents, include outreach to culturally diverse student groups, students academically at risk, and students with disabilities. In some instances, ARL respondents reported that the multicultural librarian was responsible for monitoring the collection adequacy in multicultural areas. Other duties cited include mentoring, reference work, and outreach to the community. Twenty-eight $(88 \%)$ of 32 responding libraries have formal bibliographic instruction programs with coordinators who serve the dual role of administering to the general library audience and to the special needs of such groups as the disabled, minority groups, and international students.

\section{COLLECTIONS}

More than half of the ARL libraries responding to the survey have collections exceeding three million print and nonprint items. Ninety-three percent of respondents reported that their collections on racial and ethnic minorities are integrated into their general library holdings. One library reported that its racial and ethnic minority collections are housed separately from the general collections. Examples of separately housed collections include African American Studies, Latin American Studies, East 
Asian Studies (Chinese and Japanese), Pacific Island Collection, Hawaiian Collection, Polish Collection, and Asian Languages Collections. Seventy-four percent of responding libraries said that ethnic materials are in demand, and several respondents added comments such as: "yes, in increasingly more demand" and "yes, in both print and nonprint formats." Six percent of respondents indicated only modest demand for their ethnic collections; $11 \%$ indicated that their ethnic materials are not in demand; and $9 \%$ either did not know or did not answer the question. Over two-thirds (69\%) report that African American materials are in demand at their institution. Asian resources are the second most used ethnic collection as reported by $58 \%$ of the respondents. Hispanic collections are reported by $42 \%$ and $38 \%$ said American Indian materials are in demand.

\section{CONCLUSION}

Research libraries, like librarianship in general, have a serious need to attract more members of underrepresented groups to the profession and to their staffs. Evidence gathered in this survey and from the professional literature indicates that efforts are under way, but much more needs to be done, in research libraries, in library schools, and in professional associations. Research libraries, their staff, their collections, and their services can play an essential role in and can lend considerable support to their institutions' efforts to achieve cultural diversity. Enhancing the multicultural nature of the library's collections strengthens the curriculum, and the development of strong ethnic and multicultural collections attracts scholars and researchers from various cultural backgrounds to the university and the university library. Materials collected by research libraries can and must reflect the experiences of all Americans and should be made available in a variety of formats and languages to respond to the learning styles and diverse origins of today's students.

In order to achieve a more culturally diverse environment and to establish better library communication with members of underrepresented minority groups, more research libraries need to develop a diversity or multicultural services librarian position to target traditional and special library services to diverse groups. Additionally, innovative library internship programs should be established to encourage minorities to pursue graduate study in librarianship and employment in academic and research libraries. Minority students who work as library assistants should not be overlooked. If librarians are to be successful in recruiting minority students to internships and to the profession of librarianship, librarians will need to increase their campus visibility and work in close coalition with faculty and university staff. They might develop closer ties with the career planning and placement offices on their campuses and create attractive recruitment literature which appeals to the interests of minority students. They might engage to a greater degree in cocurricular life and work with residential life advisers and other university staff to plan programming and marketing strategies.

Another avenue academic and research libraries may want to consider in their efforts to recruit people of color is the development of working partnerships with campus fraternities and sororities in which underrepresented minority students are members. Librarians will also need to take a vigorous look at their library's internal environment and assess the degree to which diversity and multiculturalism are promoted and encouraged. Knowledgeable and committed librarians and library staff might work with students to create a diversity committee to explore environmental issues on campus and in the library. They might also create an affirmative action or diversity grants program to encourage creativity and commitment to the ideals of affirmative action and to promote programmatic change. In short, librarians will need to take a more proactive stance on these issues to increase their campus and national visibility and to make librarianship a more inviting, inclusive, and rewarding professional choice. 
To improve their success rate in attracting underrepresented minorities to their staff, academic and research libraries might develop a target of opportunity program. Such a program would not substitute for a strong affirmative action program, but would instead provide additional resources and encouragement for search committees to go beyond normal methods of recruitment to attract qualified minorities. A target of opportunity program would allow the library to seek minority appointments regardless of current vacancies. In this way, an outstanding candidate could be matched to an ongoing need rather than to the happenstance of a particular vacancy at a particular time. Unlike quota systems that seek to increase minority staff to a specified level, the target of opportunity program aims to increase minority representation in the workplace through increasing the pool of known applicants and creating an appointment for a qualified individual.

Library administrators and library professional associations must give highest priority to increasing opportunities for members of underrepresented minority groups for library education and for recruitment, promotion, and professional development in academic librarianship. Library administration at the top level should and must take the responsibility and assume the leadership in encouraging the employment of people of color. Moreover, ALA-accredited library schools must also assume a greater responsibility and take a leadership position in recruiting members of culturally diverse groups to librarianship. In 1989, only 338 master's degrees in library and information science were awarded to members of the four major cultural minority groups in the United States. This record compares dismally to the 3,184 master's degrees awarded by ALA-accredited library schools to nonminority students in $1989 .{ }^{29}$ Library professional associations, library school administrators and faculty, and the directors of academic research libraries must develop creative partnerships and work cooperatively and aggressively to recruit candidates from underrepresented minority groups to academic librarianship.

\section{More research libraries need to develop a diversity or multicultural services librarian position to target traditional and special library services to diverse groups.}

There is no one answer to creating a more diverse work force in the field of librarianship, no quick fix. However, a combination of the ideas presented in this paper-emphasis on building multicultural collections; creating a position of multicultural services librarian; developing an active library internship program; providing a target of opportunity program; creating a more inclusive climate; engaging in more active and more visible recruiting - all of these and other actions should make a considerable difference over time in the composition of the profession.

Cultural diversity is a reality today on American college and university campuses, and it is one of the most important forces shaping the future of higher education. The U.S. Department of Labor estimates that minorities will comprise $26 \%$ of the work force by the year $2000 .{ }^{30}$ As academic and research libraries become greater participants in creating their own multicultural environments, they will benefit from the ideas and perspectives of different cultures to develop and strengthen their library collections and services for the benefit of all clientele. A culturally diverse library environment is its own best marketing tool to attract diverse groups to the library and to librarianship. 


\section{REFERENCES AND NOTES}

1. U.S. Bureau of the Census, Statistical Abstract of the United States: 1990 (Washington, D.C.: Govt. Print. Off., 1990), p.14-15, tables 15-16, p.17, table 19.

2. Kathleen Falcigno and Polly Guynup, "U.S. Population Characteristics: Implications for Libraries," Wilson Library Bulletin 5, no.1:26 (Sept. 1984).

3. National Center for Educational Statistics, The Condition of Education: 1990 v.2 (Washington, D.C.: Govt. Print. Off., 1990), p.76.

4. James E. Sulton, Jr., Preface to Jeri Spann, Achieving Faculty Diversity: A Sourcebook of Ideas and Success Stories (Madison, Wis.: University of Wisconsin System, 1988), p. vii; Meeting the National Need for Minority Scholars and Scholarship: Policies and Actions (Stony Brook, N.Y.: SUNY at Stony Brook, 1989), p.3.

5. Judith H. Katz, "The Challenges of Diversity," in Valuing Diversity on Campus: A Multicultural Approach, ed. Cynthia Woolbright (Bloomington: Ind.: Association of College Unions International, 1989), p.1.

6. "May Meeting to Explore Curriculum Reform in a Diverse Environment," Association of Research Libraries Newsletter no.149:1 (Mar. 12, 1990).

7. Association for Library and Information Science Education, Library and Information Science Education Statistical Report: 1988 (State College, Pa.: Association for Library and Information Science Education, 1988), p.111, table II-4-a.

8. Association for Library and Information Science Education, Library and Information Science Education Statistical Report: 1989 (Sarasota, Fla.: Association for Library and Information Science Education, 1989), p.94, table II-4-a.

9. Association for Library and Information Science Education, Library and Information Science Education Statistical Report: 1990 (Sarasota, Fla.: Association for Library and Information Science Education, 1991), p.133-34, table II-4-a.

10. Betty M. Vetter, Professional Women and Minorities: A Manpower Data Resource Service (Washington, D.C.: Commission on Professionals in Science and Technology, 1991), p.98.

11. U.S. Bureau of the Census, Statistical Abstract, p.389, table 645.

12. Association of Research Libraries, ARL Annual Salary Survey: 1990 (Washington, D.C.: Association of Research Libraries, 1991), p.7. The author discovered an error in the total number of Asian librarians reported in the ARL Survey and informed ARL. The corrected figures are cited in this article.

13. Edith Maureen Fisher and others, "Recruiting the Underrepresented to Academic Libraries," College \& Research Libraries News 51:1019 (Dec. 1990).

14. Ibid., p.1028.

15. Sarah M. Pritchard, "ARL Board Moves to Form Task Force on Minority Recruitment," ARL: A Bimonthly Newsletter of Research Library Issues and Actions no.151:9 (July 4, 1990).

16. "ARL Booth to Showcase Cultural Diversity," Association of Research Libraries Newsletter no.149:11 (Mar. 12, 1990).

17. Christine Crocker and others, "Cultural Diversity Programs Highlighted," $A R L: A$ Bimonthly Newsletter of Research Library Issues and Actions no.152:9 (Sept. 21, 1990).

18. University of Michigan Library, Point of Intersection II: The University Library Moves Toward Diversity (Ann Arbor, Mich.: Univ. of Michigan, 1990), p.ii.

19. Graceanne A. DeCandido, "Mentor Program to Recruit Hispanics to Librarianship Grows at UCLA," Library Journal 113:108 (Sept. 1, 1988).

20. Allan G. Dyson, "Reaching Out for Outreach: A University Library Develops a New Position to Serve the School's Multicultural Students," American Libraries 20:952-54 (Nov. 1989); University of Michigan Library, Point of Intersection II, p.6.

21. Delbert C. Miller, Handbook of Research Design and Social Measurement, 5 th ed. (Newbury Park, Calif.: Sage, 1991), p.141.

22. Association of Research Libraries, ARL Annual Salary Survey: 1990, p.7.

23. Jeanne M. K. Boydston, "Hiring Practices, Equal Employment Opportunity and Affirmative Action in ARL Libraries," Journal of Library Administration 14 (1991, in press).

24. Em Claire Knowles, "How to Attract Ethnic Minorities to the Profession," Special Libraries 81:143 (Spring 1990).

25. Association of Research Libraries, ARL Annual Salary Survey: 1990, p.8.

26. Joseph A. Boisse and Connie V. Dowell, "Increasing Minority Librarians in Academic Research Libraries," Library Journal 112:52 (Apr. 15, 1987). 
27. Fisher and others, "Recruiting the Underrepresented to Academic Libraries," p.1,017.

28. Dyson, "Reaching Out for Outreach," p.954.

29. Association for Library and Information Science Education, Library and Information Science Education Statistical Report: 1990 , p.107, table II-3-a.

30. Susan Gurrow, "Membership Input Sought on Diversity Issues," ARL: A Bimonthly Newsletter of Research Library Issues and Action 154:5 (Jan. 4, 1991).

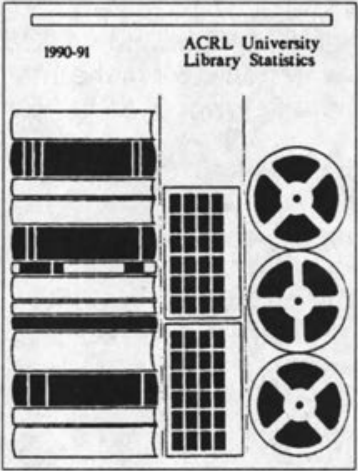

$\$ 69.95$

(\$39.95 for

ACRL members)

80 pp, 1992

ISBN 0-8389-7587-9

Order Department

ALA Publishing Services

50 East Huron Street

Chicago, IL 60611

Or call toll-free

1-800-545-2433

Fax: $312-944-2641$

\section{ACRL}

University Library Statistics, 1990-91

Association Of

COLLEGE

\& RESEARCH

LIBRARIES

Association Of

This edition provides data on 106 participating libraries from the United States and Canada.

The general categories of library data collected include

- collections

- personnel

- expenditures

- interlibrary loans

C OLLEGE

\& RESEARCH

LIBRARIES

AsSOCIATION OF

C OLLEGE

\& RESEARCH

LIBRARIES

Association Of

The institutional data elements reported include degrees offered, enrollment size, and faculty size.

Use these data in making management decisions concerning your library.

Purchasers of this book may request a free copy of the data in machine-readable form.
COLLEGE

\& RESEARCH

LIBRARIES

A DIVISION OF THE

AMERICAN LIBRARY

ASSOCIATION 